Osoba i doświadczenie mistyczne (2) „Filozofia Chrześcijańska” 14 (2017), s. 71-86 doi: $10.14746 /$ fc. 2017.14 .4

\author{
MACIEJ MANIKOWSKI \\ Uniwersytet Wrocławski \\ Wydział Nauk Społecznych
}

\title{
Ekstasis i epektasis jako dwa elementy opisujące doświadczenie mistyczne według Grzegorza z Nyssy
}

Grzegorz z Nyssy, filozof, teolog i mistyk IV wieku, należy do najważniejszych myślicieli chrześcijańskich, którego trzeba nie tylko uznać za jednego z twórców teologii trynitarnej, ale również za ojca chrześcijańskiej filozofii. Na chrześcijańskim Wschodzie uznawany za „Kolumnę Ortodoksji”, przez wieki zapomniany lub niedoceniany na chrześcijańskim Zachodzie, od połowy $\mathrm{XX}$ wieku odzyskuje należne mu miejsce w historii teologii, filozofii i mistyki. Wreszcie, odkryto i potwierdzono wielką rolę biskupa Nyssy w kształtowaniu się chrześcijańskiej filozoficznej mistyki, uznając go za jednego z jej oj ców założycieli ${ }^{1}$. Ta specyficzna nieobecność Grzegorza z Nyssy w tradycji chrześcijańskiego Zachodu wynikała $\mathrm{z}$ dwóch przynajmniej powodów. Po pierwsze, $z$ nietłumaczenia jego dzieł na język łaciński (coraz słabsza była znajomość greki na Zachodzie), za wyjątkiem traktatu De hominis opificio, a po drugie, z dominującej pozycji Augustyna i jego myśli filozoficznej i teologicznej, w tym i jego rozumienia doświadczenia mistycznego, choć jest to rozumienie - w wielu miejscach - bardzo podobne ${ }^{2}$. Nie oznacza to jednak, że myśl biskupa Nyssy nie była, choćby pośrednio, a może nawet jako nierozpoznawalna co do autorstwa, obecna w tradycji chrześcijańskiego Zachodu. Jeśli przyjąć hipotezę, że dzieło teologiczne Pseudo-Dionizego Areopagity jest pod ogromnym wpływem myśli Grzegorza (a może jest wręcz jego parafrazą),

${ }^{1}$ Por. B. McGinn, Obecność Boga. Historia mistyki zachodniochrześcijańskiej, thum. T. Dekert, Kraków 2009, s. 198; H. Crouzel, Grégoire de Nysse est-il fondateur de la théologie mystique? Une controverse récente, „Revue d'ascétique et de mystique”, vol. 33, no. 130, 1957, s. 189-202.

2 Por. tamże, s. 199. 
a znane jest ono na Zachodzie dzięki tłumaczeniom na język łaciński i adaptacjom w myśli Jana Szkota Eriugeny czy Wilhelma z Saint-Thierry, to można spróbować poszukiwać specyficznych elementów mistyki biskupa Nyssy u wielu myślicieli średniowiecznego łacińskiego chrześcijaństwa, jak choćby u Mistrza Eckharta.

Mistyka Grzegorza z Nyssy jest w pełni konsekwencją jego myśli teologicznej i filozoficznej, a w szczególności jest konsekwencją jego antropologii, będącej z kolei konsekwencją koncepcji Boga i kosmologii. Jak pisze Bernard McGinn: „Stworzenie ortodoksyjnej teologii trynitarnej stanowiło przełom w historii myśli chrześcijańskiej, jeden z tych, które wywarły wpływ na wszystkie aspekty późniejszego chrześcijaństwa, w tym na mistykę" ". Inaczej jednak niż McGinn, uważam, że decydujący wpływ na mistykę tak wczesnochrześcijańską, jak i późniejszą, miała przede wszystkim chrześcijańska antropologia, a nie jedynie teologia trynitarna. Upraszczając nieco, teologia trynitarna, zwłaszcza ojców kapadockich na Wschodzie i Augustyna czy Ryszarda ze św. Wiktora na Zachodzie, jednoznacznie przyczyniła się do pojmowania chrześcijańskiego Boga jako jednego w Naturze i troistego w Osobach, wprowadzając bardzo klarowne rozróżnienia terminologiczne między naturą (istotą) a osobami (hipostazami) ${ }^{4}$. Z tych ważnych teologicznie rozstrzygnięć jeszcze nie wynika wprost to, co dla rozumienia doświadczenia mistycznego jest najważniejsze, czyli to, że człowiek w swym poznawaniu Boga - podobnie jak biblijny Mojżesz - wychodzi z siebie i wkracza do obłoku, gdzie jest Bóg, wychodzi ze swej materialności, by - pokonując ją - wejść w to, co niematerialne i niecielesne, a poprzez to podobne Bogu.

Analizując elementy charakteryzujące doświadczenie mistyczne w myśli filozoficznej i teologicznej Grzegorza z Nyssy, chciałbym omówić wpierw trzy płaszczyzny, będące niejako wprowadzeniem do właściwej analizy doświadczenia mistycznego. Po pierwsze, trzeba zrekonstruować Nysseńską koncepcję Boga; po drugie, zrekonstruować jego koncepcję świata stworzonego i - po trzecie - jego antropologię, uznając tę ostatnią za zasadniczy klucz interpretacyjny doświadczenia mistycznego. Mówię tutaj oczywiście o rek on s truk cj i, i wyraźnie to podkreślam, ponieważ - po pierwsze - Grzegorz z Nyssy wiele elementów swej nauki umieszczał w różnych dziełach i w różnych kontekstach filozoficznych, a chodzi o - po drugie - wskazanie pewnych węzłowych punktów potrzebnych do analizy doświadczenia mistycznego, a nie o całościowe przedstawienie filozofii czy teologii biskupa Nyssy, zresz-

3 Tamże, s. 200.

4 Uproszczenie, o którym tutaj piszę, wynika z tego, że nie podejmuję w tym miejscu analizy różnego sposobu podchodzenia do zagadnienia Trójcy Świętej na Wschodzie (najpierw trzy osoby, a potem jedność natury) i na Zachodzie (najpierw jedność natury, a potem troistość osób). 
tą, Nysseńczyk z założenia nie budował spójnego systemu filozoficznego czy teologicznego.

\section{Grzegorza z Nyssy nauka o Bogu}

Jako teolog i filozof Grzegorz z Nyssy jest dzieckiem swej epoki. Będąc dość dobrze wykształcony, w umiejętny sposób łączył ze sobą tradycję biblijną i filozoficzną. Wskazuje się zazwyczaj, że biskup Nyssy znał dobrze tradycję filozofii platońskiej, czytał bowiem dialogi Platona, ale zapewne znał również Enneady Plotyna i inne dzieła medio- i neoplatoników. Znał także dzieło filozoficzno-teologiczne Orygenesa, gdyż to on jako pierwszy w traktacie $O$ zasadach dokonał pierwszej systematyzacji nauki chrześcijańskiej ${ }^{5}$. Te źródła miały decydujący wpływ na myślenie Grzegorza tak o Bogu, jak i świecie stworzonym czy człowieku. Można dostrzec tutaj pewien dylemat, z którym mieli do czynienia pierwsi chrześcijańscy teologowie i filozofowie - jeżeli mieliby dokonywać syntezy myśli filozoficznej z objawieniem, to czy należy uzgadniać objawienie z Platonem, czy też Platona z objawieniem? To oczywiście pewien poręczny skrót myślowy, ale - jak sądzę - pokazujący istotę problemu. Nie podlegała przecież wątpliwości decydująca pozycja objawienia, ale również nie podlegał wątpliwości autorytet filozoficzny Platona (by tylko o nim wspomnieć), zwanego bardzo często „starożytnym teologiem”. Można tutaj zaznaczyć, że chcąc uczynić chrześcijaństwo bardziej powszechnym, trzeba było je niejako ubrać w grecką terminologię filozoficzną. Nie wnikając oczywiście w to, co w nauce Grzegorza jest biblijne, a co platońskie (greckie), wskazać trzeba na trzy płaszczyzny pozwalające na właściwe zrozumienie jego nauki o Bogu - po pierwsze, pojmowanie Boga jako Byt Najwyższy, po drugie - podkreślanie niepoznawalności Jego Natury (czy Istoty) oraz - po trzecie - wynikające z nauki o niepoznawalności natury Boga wyróżnienie w Nim niepoznawalnej Natury i poznawalnych Energii ${ }^{6}$.

Podobnie jak greccy filozofowie, Grzegorz z Nyssy wskazuje, że Boga trzeba pojmować jako najwyższy i najdoskonalszy Byt. W traktacie Oratio catechetica magna pisze: „Wszyscy się zgadzają, że Boga należy uważać za nie tylko potężnego, lecz także za sprawiedliwego, dobrego, mądrego i przyznać

5 Por. A.H. Armstrong, The Self-Definition of Christianity in Relation to Later Platonism, w: Jewish and Christian Self-Definition I: The Saping of Christianity in teh Second and Third Centuries, red. E.P. Sanders, London 1984; A.H. Armstrong, Platonic Elements in St. Gregory of Nyssa'a Doctrine of Man, „Dominican Studies”, vol. 1, no. 2, 1948.

${ }^{6}$ Ponieważ w języku greckim mamy tutaj termin ousia, oddawany najczęściej w języku polskim jako 'istota' lub 'natura', jak również jako 'substancja', w tekście tym będę zamiennie stosował na thumaczenie tego terminu wyrażenia 'istota' $i$ 'natura'. 
$\mathrm{Mu}$ trzeba każdą poznaną przez nas doskonałość"' Kluczowe w tym fragmencie jest to, że - zdaniem biskupa Nyssy - Bogu trzeba przyznać każdą znaną nam doskonałość, a co za tym idzie - Boga trzeba uznać za Byt Doskonały, a to Go wyróżnia w świecie wszystkich bytów. Drugim określeniem, które ponownie wyróżnia Boga w świecie bytów, jest pojmowanie Go jako „Byt Prawdziwy” czy dokładniej jako „Byt Rzeczywisty”. W traktacie De vita Moysis czytamy, że ,prawdziwym życiem jest tylko rzeczywisty Byt"8, co wprost odczytywane być powinno jako podkreślenie jedyności bytowej Boga. Inaczej rzecz ujmując, Bóg, będąc prawdziwym Bytem, rzeczywistym Bytem, jest Bytem Istotnie Istniejącym, by użyć Platońskiego sformułowania, co - raz jeszcze - wskazuje na Jego metafizyczną wyjątkowość ${ }^{9}$. Jednakże ta metafizyczna wyjątkowość prowadzi do wyjątkowości epistemologicznej.

Odczytując poprzednią myśl Grzegorza z Nyssy w szerszym nieco kontekście, dochodzimy do wniosku, że metafizyczne uwarunkowania Bytu Boga prowadzą do zagadnienia Jego poznawalności. Biskup Nyssy wprost mówi, że pierwszą i zasadniczą cechą Boga jest Jego niepoznawalność. W obszerniejszym fragmencie tego traktatu czytamy:

Pismo nie mówi tu [Wj 33,20 - przyp. M.M.] wcale, że widzenie Boga może sprowadzić na patrzących śmierć. Jak bowiem widok Życia mógłby sprowadzić śmierć na tych, którzy się do niego zbliżają? Ponieważ jednak Bóstwo jest Dawcą życia, a właściwością natury Bożej jest przekroczenie wszelkiej właściwości, zatem ktoś, kto uważa, że Bóg jest istotą poznawalną, odstępuje od Tego, który jest rzeczywistym Bytem, a zwraca się ku czemuś, co jest tylko zmysłowym wrażeniem bytu, i zostaje pozbawiony życia ${ }^{10}$.

Grzegorz z Nyssy wskazuje w tym fragmencie na dwie istotne cechy Boga. Po pierwsze, nawet wtedy, kiedy przyznajemy Bogu każdą z poznanych przez nas właściwości, okazuje się ostatecznie, że On, dzięki swej wyjątkowości, przekracza każdą z nich. Inaczej rzecz ujmując, ponieważ Bóg jest Źródłem wszystkiego, przekracza jednocześnie wszystko to, co od Niego pochodzi. W tym sensie Bóg jest prawdziwym Bytem i rzeczywistym Bytem, ponieważ gdyby rzeczy stworzone były bytami, On jako ich Stwórca musiałby być nie-

7 Oratio catechetica magna, § 20. Por. De vita Moysis, II.153. Odwołuję się tutaj do polskich thumaczeń według wydań (odpowiednio): Wielka mowa katechetyczna, tłum. W. Kania, w: Grzegorz z Nyssy, Pisma wybrane, Warszawa 1974; Życie Mojżesza, tłum. S. Kalinkowski, Kraków 2009 (cyfra rzymska oznacza księgę, cyfra arabska - paragraf).

${ }^{8}$ De vita Moysis, dz. cyt., II.235.

9 Por. B. McGinn, P. Ferris McGinn, Mistycy wczesnochrześcijańscy. Wizje Boga u mistrzów duchowych, tłum. E.E. Nowakowska, Kraków 2008, s. 104.

10 De vita Moysis, II.234. Cytuję za poskim wydaniem: Grzegorz z Nyssy, Życie Mojżesza, thum. S. Kalinkowski, Kraków 2009 (cyfra rzymska oznacza księgę, cyfra arabska - paragraf). 
bytem (me on). Jest to bardzo wyraźne e c h o myśli neoplatońskiej. Po drugie, konsekwentnie, takie pojmowanie Boga prowadzi do Jego niepoznawalności. Warto tutaj podkreślić, że z przytoczonego fragmentu tekstu wynika, że nieprawdziwa jest teza mówiąca, że Bóg jest pojmowalny poprzez swe właściwości, bowiem biskup Nyssy wskazuje, że niewłaściwie postępuje ten, kto „Zwraca się ku czemuś, co jest tylko zmysłowym wrażeniem bytu”"11. W tym miejscu, ale nie tylko, Nysseńczyk zaznacza, że chodzi o niepoznawalno ść natury Boga, a nie o niepoznawalność Boga w ogóle. Pisze: „Prawdziwym Życiem jest tylko rzeczywisty Byt, a Byt ten jest niedostępny dla poznania" 12 .

W tym miejscu trzeba zadać zasadnicze pytanie dotyczące poznawalności. Czy zatem owa niepoznawalność Boga wynika z natury samego bytu Boga, byłaby to zatem niepoznawalność metafizyczna, czy też niepoznawalność ta wynika jedynie z niedoskonałości naszego ludzkiego aparatu poznawczego, osłabionego choćby skutkami grzechu pierworodnego? Niepoznawalność Boga jest wedle Grzegorza z Nyssy przede wszystkim niepoznawalnością metafizyczną, a zatem niepoznawalnością wynikającą z samej natury Bytu Boga, a dopiero później, w konsekwencji, jest również i niepoznawalnością epistemologiczną, wynikającą nie tyle z niedoskonałości naszego aparatu poznawczego, ile $z$ konstytucji bytu człowieka. Nie wnikając w tym miejscu w bardziej szczegółowe analizy, biskup Nyssy uznaje, że ponieważ „Bóstwo z natury swej jest nieograniczone, nie ogarniają Go żadne granice"13, to jest również z natury swej niepoznawalne. Metafizyczna nieograniczoność skutkuje metafizyczną niepoznawalnością, czyli niepoznawalnością natury Boga. Z tej metafizycznej niepoznawalności wynika, jako logiczna konsekwencja, niepoznawalność epistemologiczna, o której Nysseńczyk tak pisze w homiliach In ecclesiastem: „Kto zawzięcie próbuje objąć słowem Nieogarnionego, zaprzecza, że On jest ponad wszystkim, bo wyprowadza naprzeciw Niego własne słowa, sądząc, że On jest taki, jakim określają Go słowa, a nie wie, że stwierdzenie, iż Bóstwo przewyższa możliwości poznawc ze, stanowi najlepszą definicję prawdziwego Istnienia"14. Dostrzec trzeba jednak jeszcze i to, że na niepoznawalność Boga, tak w Jego naturze, jak i ze

${ }^{11}$ Pseudo-Dionizy Areopagita mówi tutaj o „tkwiących w bytach”. Por. Pseudo-Dionizy Areopagita, Teologia mistyczna, I.1.2. Podaję za: Pseudo-Dionizy Areopagita, Pisma teologiczne, thum. M. Dzielska, Kraków 2005 - paginacja: cyfra rzymska oznacza rozdział, cyfra arabska - paragraf, druga cyfra arabska - akapit w paragrafie.

12 Tamże, II.235.

13 Tamże, II.236 (wyróżnienie moje - MM).

${ }^{14}$ In ecclesiastem, VIII, 9 - wyróżnienie moje - MM. Podaję według polskiego thumaczenia: Grzegorz z Nyssy, Homilie do Eklezjastesa, tłum. M. Przyszychowska, Kraków 2009. Paginacja: cyfra rzymska oznacza nr homilii, cyfra arabska - akapit. 
względu na niewystarczalność naszego aparatu poznawczego, ma wpływ Nysseńska kosmologia i antropologia, a w szczególności usytuowanie człowieka pomiędzy innym bytami stworzonymi przez Boga.

\section{Grzegorza z Nyssy nauka o świecie stworzonym}

W swej kosmologii biskup Nyssy wyraźnie opowiada się za prymatem biblijnej nauki o stworzeniu świata przez Boga. Zarówno w dziełach egzegetycznych, jak i dogmatycznych, nie podlega to jakiejkolwiek wątpliwości. Być może jest to również skutkiem takiego odczytywania Platońskiego dialogu Timaios, który rozumiano jako ukazujący stwórcze działanie Ojca świata. To, co jest oryginalnym wkładem Nysseńczyka, to umiejętne połączenie Platońskiej kosmologii i metafizyki z biblijnym objawieniem. Podkreśla on bowiem, że prymarne nie jest dzielenie bytów na materialne i duchowe (czyli na materię i idee), ale na stworzone i niestworzone. Zgodnie z modelem biblijnym, Bóg jest jedynym Bytem Niestworzonym, a wszystko, co nie jest Nim, jest stworzone. Dopiero pośród bytów stworzonych dokonujemy podziału na byty stworzone niematerialne i byty stworzone materialne. Kolejną nowością w stosunku do tradycji Platońskiej jest stwierdzenie, że stworzonymi bytami duchowymi wcale nie są idee, ale istoty duchowe, i to istoty dwojakiego rodzaju - po pierwsze te, które są stworzone jako duchowe i zawsze takie pozostają, a więc aniołowie, oraz te, które są stworzone jako duchowe, ale niekiedy istnieją wcielone w materię, czyli ludzkie dusze. Natomiast pośród stworzonych bytów materialnych Grzegorz wymienia byty nieożywione i ożywione, te zaś z kolei dzieli na ożywione zmysłowe i ożywione rozumowe. Tym samym w jego strukturę rzeczywistości wpisany zostaje każdy byt: Bóg jako jedyny Byt Niestworzony, aniołowie jako stworzone byty duchowe, materia nieożywiona jako stworzony byt materialny, zwierzęta jako stworzone byty materialne zmysłowe oraz człowiek jako stworzony byt materialny rozumowy. Jednocześnie, o czym będzie jeszcze mowa, człowiek poprzez to, że ma duszę, czyli stworzony byt duchowy, oraz ciało, czyli stworzony byt materialny, łączy w sobie dwa królestwa bytów, czyli to, co materialne, i to, co niematerialne, $\mathrm{i}$ jest on jedynym takim bytem w stworzonym kosmosie ${ }^{15}$.

Kosmologia i metafizyka Grzegorza z Nyssy wydaje się w punkcie zasadniczym dość oczywista: istnieją dwa rodzaje bytów - niestworzony i stworzony, a wszelkie znane nam z historii filozofii podziały czy klasyfikacje dotyczą

15 Por. De anima et resurrectione, 46. Podaję według polskiego thumaczenia: Grzegorz z Nyssy, $O$ duszy i zmartwychwstaniu, thum. W. Kania, w: Grzegorz z Nyssy, Pisma wybrane, Warszawa 1974. 
jedynie tego, co jest stworzone. Jednak w tym tak radykalnym, biblijnym dodajmy, podziale, kryje się jeszcze jedna myśl metafizyczna, będąca osią dla całego myślenia biskupa Nyssy. W traktacie Oratio catechetica magna czytamy bowiem:

Rozróżniamy dwojakie poznanie, zależne od tego, czy się ono odnosi do rzeczy zmysłowych, czy duchowych. Nie ma w naturze bytów niczego, co by wychodziło poza ten podział. Wymienione płaszczyzny oddziela wielka przepaść, tak że poznanie zmysłowe nie ma cech duchowych i duchowe zmysłowych. Zachodzi między nimi wyraźne przeciwieństwo cech. Duchowa natura jest czymś bezcielesnym, niedotykalnym, czymś co nie ma kształtu, zmysłowa zaś, jak już nazwa wskazuje, opiera się na poznaniu zmysłowym ${ }^{16}$.

Ponieważ istnieją dwa sposoby poznawania, mówi Grzegorz z Nyssy, muszą zatem istnieć dwa odpowiadające im przedmioty poznania, czyli to, co zmysłowe, i to, co niezmysłowe. Ponieważ zaś te dwa przedmioty diametralnie się od siebie różnią, musi istnieć również i metafizyczna przepaść między nimi, dodać można - przepaść niepokonywalna. Jednak jest to tylko pierwszy poziom tego zagadnienia. Zastanówmy się, co będzie jeśli wy miarem, rozumiejąc to pojęcie raczej metaforycznie, uczynimy nie tylko różnicę materialności i niematerialności, ale również różnicę bycia stworzonym i bycia niestworzonym. Okazuje się, że koncepcja metafizycznej przepaści, metafizycznej diastasis czy diastema, powinna się rozszerzyć, by wskazać, że zasadnicza metafizyczna i niepokonywalna przepaść istnieje pomiędzy tym, co niestworzone, i tym, co stworzone, dopiero w drugim aspekcie przepaść ta dotyczy tego, co materialne i niematerialne, czy też tego, co zmysłowe i niezmysłowe ${ }^{17}$. Zatem zasadniczą metafizyczną cechą Boga jest to, że metafizycznie, a także i ontologicznie, a co za tym idzie, również i epistemologicznie, różni się On od tego wszystkiego, co Nim nie jest. W tym miejscu zakotwiczona jest, jak sądzę, metafizyczna teza o niepoznawalności Boga w Jego naturze, ponieważ to właśnie $\mathrm{z}$ owej zasadniczej cechy Boga, jaką jest metafizyczna różnica od świata stworzonego, wynika Jego niepoznawalność, a w konsekwencji również i ludzkie kłopoty z poznaniem Boga. Jak można znaleźć wyjście z tego impasu? Oryginalność Nysseńczyka nie polega na tym, że szuka rozwiązania w świecie czy w człowieku, ale że szuka go w samym Bogu.

16 Oratio catechetica magna, dz. cyt., § 6.

17 Por. T.P. Verghese, Diastema and Diastasis in Gregory of Nyssa. An Introduction to a Concept and the Posing of a Problem, w: Zweites Internationales Kolloquium über Gregor von Nyssa, hrsg. von H. Dörrie, M. Altenburger, U. Schram, Leiden 1976, s. 243-260; D.L. Balás, Methousia Theou. Man's Participation in God's Perfection According to Saint Gregory of Nyssa, „Studia Anselmiana" vol. 55, 1966. 
Filozoficzna konsekwencja może być tylko jedna: w Bogu, w samym Jego Bycie, musi być to, co poznaniu nie jest dostępne, by zachować naukę o niepoznawalności Boga wynikającą z Jego Natury, oraz to, co jest dla człowieka poznawalne. Podkreślam raz jeszcze, że jest to konsekwencja filozoficzna, do której dochodzimy, prowadząc swe analizy, jest to konsekwencja naszego myślenia o Bogu, a nie coś, co wynika z wglądu w istotę i naturę Boga, która jest niepoznawalna, bowiem „Boga nikt nigdy nie oglądał” (J 1,18). W traktacie De vita Moysis przeczytamy: „Trzeba wierzyć, że Bóstwo istnieje, ale nie zastanawiać się nad tym, jakie Ono jest, jak wielkie, skąd pochodzi i w jaki sposób istnieje, ponieważ są to sprawy niedające się ogarnąć umysłem" ${ }^{18}$. Widać tutaj wyraźnie, jak biskup Nyssy próbuje pogodzić ze sobą biblijne objawienie, szczególnie pochodzące z pism św. Jana Apostoła, z filozoficzną możliwością mówienia o Bogu, choć i on zapewne znał pochodzące z Platońskiego dialogu Timaios zastrzeżenie co do poznawalności „Ojca i Twórcy tego świata”19.

Rozróżnienie w Bogu na to, co jest niepoznawalne, czyli Jego niedostępną naturę lub istotę, oraz na to, co jest poznawalne, oddawane terminem energeiai, czyli energie, nie jest oryginalnym pomysłem Grzegorza z Nyssy. Jak pokazuje to w cyklu artykułów George Habry ${ }^{20}$, pochodzi ono z tradycji filozoficzno-teologicznej, której źródeł należy szukać w hellenistycznej myśli Filona z Aleksandrii. O ile jednak Aleksandryjczyk wprowadza to rozróżnienie, by rozwiązać zasadniczy problem myśli żydowskiej, jakim jest pogodzenie transcendencji i immanencji Boga ${ }^{21}$, o tyle biskup Nyssy, wprowadzając to rozróżnienie, chce uniknąć możliwych kłopotów wynikających z biblijnego nakazu poznania Boga, bo na tym polega życie wieczne (J 17,3), z jednoczesną biblijną deklaracją, że „Boga nikt nigdy nie oglądał” (J 1,18), czy też z tym, że zobaczenie Boga skutkuje śmiercią człowieka.

Warto w tym miejscu zwrócić uwagę jedynie na dwa aspekty nauki Nysseńczyka o poznawaniu poprzez Boskie Przejawy, Wypływy czy Działania, bo tak są określane te części Boga, które są poznawalne. W traktacie De perfectione czytamy:

[Paweł] zawarł jedynie pewne wzmianki o swym doświadczeniu tajemnicy - na miarę tego, co słuchacze mogli pojąć. Powiedział tyle, ile daje się wyrazić słowem. Gdy poznał wszystko, co człowiek może pojąć o naturze Bożej, wyjawił, że istota najwyższego Bytu jest nieosiągalna i niedostępna dla ludzkiego rozumu. Kiedy Paweł mówi o tym, co można w tym Bycie kontemplować - pokój, moc,

${ }^{18}$ De vita Moysis, I. 47.

19 Por. Platon, Timaios, 28c. Platon, Timajos. Kritias, tłum. P. Siwek, Warszawa 1986, s. 35.

${ }^{20}$ Por. G. Habra, The Patristic Sources of the Doctrine of Gregory Palamas on the Divine Energies. Part II: The Three Cappadocians, „The Eastern Churches Quarterly”, vol. XII, no. 7, 1958.

${ }^{21}$ Por. H. Pietras, Początki teologii Ojców Kościoła, Kraków 2000, s. 163-164. 
życie, sprawiedliwość, światło, prawdę i tym podobne - stwierdza też, że mówienie o Nim jest całkowicie niemożliwe. Powiedział przecież, że Boga nie można widzieć. „Nikt z ludzi nigdy Go nie widział i nie może zobaczyć” $(1 \mathrm{Tm} 6,16)$. Dlatego też, gdy poszukiwał, jak określić to, co nieuchwytne dla umysłu, i nie znalazł odpowiedniego słowa, by wyrazić sens tego, co nieogarnione, „chwałą” $i$, istotą" nazwał to, co przekracza wszelkie dobro i co jest niepojęte i niewyrażalne. Stąd Najwyższy Byt pozostawił nienazwany ${ }^{22}$.

Z jednej strony mamy wyraźne uszanowanie biblijnego stwierdzenia czy potwierdzenia niepoznawalności Boga, $\mathrm{z}$ drugiej strony mamy próbę jej przezwyciężenia choćby w tym, że Grzegorz, za św. Pawłem, mówi o „Chwale Boga" jako o tym, co - obrazowo czy symbolicznie - jest z Niego poznawalne. To przecież właśnie pod postacią swej chwały objawiał się Jahwe Izraelowi w Namiocie Spotkania czy w świątyni jerozolimskiej, a także chwałę ujrzał Mojżesz, gdy został postawiony w skalnej rozpadlinie. Ponieważ, ponownie obrazowo, Chwała jest tym, co jest dookoła Boga, można powiedzieć, że nadal Bóg w swej naturze czy istocie jest niepoznawalny, a jednak daje się poznawać w tym, co jest wprawdzie Nim samym, ale jest niejako dookoła Niego, czyli w swej Chwale. Jest Ona, podobnie jak sam Bóg, niestworzona.

Jednocześnie trzeba zwrócić uwagę na wymienione przez Nysseńczyka boskie atrybuty, takie jak: pokój, moc, życie, sprawiedliwość, światło, prawdę, jak i wiele innych. Co to jest? Nie jest to Bóg w swej naturze, ale - ponownie to, co jest d o ok oła Niego, a w tym wypadku są to Jego działania, dokładniej - Jego działania względem świata stworzonego. Tym samym niepoznawalny w swej naturze Bóg może być poznawalny w swych działaniach, energiach czy - obrazowo - wypływach. Grzegorz z Nyssy ujmuje to tak:

Gdyby było możliwe rozważać naturę Bożą samą w sobie i znaleźć w jej przejawach zarówno to, co do niej należy, jak i to, co jej obce, nie potrzebowalibyśmy żadnych innych racji ani znaków, by wyjaśnić przedmiot naszego badania. Ponieważ przewyższa ona jednak poznanie badacza, a my jedynie na sposób przypuszczeń wyciągamy wnioski na podstawie pojedynczych znaków o tym, co chce ujść naszemu poznaniu, musimy dać się prowadzić za rękę poprzez wszelkie działania (dia ton energeion) do zbadania boskiej natury ${ }^{23}$.

${ }^{22}$ De perfectione, 35-36. Według polskiego thumaczenia: Grzegorz z Nyssy, O doskonałości, thum. J. Naumowicz, w: Grzegorz z Nyssy, O naśladowaniu Boga. Pisma ascetyczne, Kraków 2001. Paginacja - cyfra arabska oznacza numer paragrafu.

${ }^{23}$ De Trinitate, 85. Według polskiego tłumaczenia: Grzegorz z Nyssy, Do Eustacjusza o Trójcy Świętej, thum. T. Grodecki, w: Grzegorz z Nyssy, Drobne pisma trynitarne, Kraków 2001, paginacja - numer strony polskiego wydania. 


\section{Grzegorza z Nyssy nauka o czlowieku}

Antropologia Nysseńczyka jest wypadkową trzech wzajemnie się na siebie nakładających płaszczyzn. Pierwszą jest oczywiście tradycja biblijna, a więc znajdująca się w Księdze Rodzaju opowieść o stworzeniu człowieka, na którą nakładana jest druga płaszczyzna, pochodząca z tradycji filozoficznej, głównie Platona i Orygenesa, oraz, jako trzeci element, wzbogacana własnymi, oryginalnymi pomysłami filozoficznymi biskupa Nyssy. Odczytując biblijną opowieść o stworzeniu człowieka, Grzegorz z Nyssy zwraca uwagę na to, że są to dwa, dopełniające się wprawdzie, ale dwa opisy stworzenia człowieka. Wyciąga z tego filozoficzny wniosek, podjęty w późniejszej tradycji przez m.in. Jana Szkota Eriugenę, że Bóg w pierwszym akcie stwórczym powołał naturę człowieka, bo to miałyby oznaczać słowa o stworzeniu ,człowieka, mężczyzny i niewiasty”, a dopiero w drugim akcie stwórczym powołał do istnienia człowieka złożonego z ciała i duszy. Oczywiście, kiedy mówimy o pierwszym i drugim akcie stwórczym Boga, nie mamy na myśli płaszczyzny fizycznej czy chronologicznej, ale metafizyczną. Takie rozumienie stworzenia człowieka pokazuje, że to, co jest wszystkim ludziom wspólne, to, co pozwala ich niejako ,zaliczać” do grona ludzi, to właśnie wspólna im natura, czyli człowieczeństwo, coś, co jest duchowe i idealne z uwagi na swą niecielesność. Używając języka teologicznego, można powiedzieć, że wszyscy ludzie są sobie współistotni czy współsubstancjalni, ponieważ mają tę samą naturę. To, co ich różnicuje, powiązane jest z ich cielesnością, choć oczywiście, biologicznie rzecz ujmując, jest ona u wszystkich podobna, oraz z tym, że każdy z ludzi ma swoją własną, indywidualną i niepowtarzalną duszę, która jest bezpośrednio stwarzana przez Boga. W tym sensie trzeba powiedzieć, że zagadnienie stworzenia człowieka zostaje filozoficznie wyjaśnione.

Człowiek jednak, co jest ważne, jest specyficznym stworzeniem. Po pierwsze, jest bytem bezpośrednio stworzonym przez Boga, jest też - po drugie jedynym bytem stworzonym przez Boga na Jego obraz i podobieństwo, po trzecie, jest też bytem, który łączy w sobie dwa światy. Omawiając kosmologię Grzegorza z Nyssy, wskazywałem na to, że nakładając na siebie dwie tradycje - biblijną i Platońską - Nysseńczyk podkreśla istnienie dwóch stworzonych przez Boga sfer bytów: duchowych i materialnych. Ma to konsekwencje w antropologii filozoficznej. Ponieważ człowiek jest stworzony przez Boga jako istota cielesno-duchowa, poprzez swe ciało jest stworzonym bytem materialnym, a poprzez swą duszę jest stworzonym bytem duchowym. Dlatego jego pozycja w świecie jest wyróżniona, bo jednocześnie przynależy do sfery stworzonych bytów materialnych i sfery stworzonych bytów duchowych. Jego wyróżniona pozycja wynika również i z tego, że ma duszę, w której cały czas umieszczony jest „obraz i podobieństwo Boga” albo cały czas ten „obraz i podobieństwo" są tam przechowy wa ne. 
Czym zatem jest dusza człowieka? Grzegorz z Nyssy rozpoczyna, można powiedzieć, od odrzucenia dwóch znanych modeli wythumaczenia istoty duszy: Platońskiego i Arystotelesowskiego. Temu drugiemu zarzuca wprost, pomimo doceniania wielkiego wkładu Stagiryty do badań naukowych, błąd polegający na uznaniu duszy za śmiertelną, a wynika on z niezrozumienia tego, że dusza została stworzona przez Boga, który jest Dawcą życia, a nie śmierci. Odrzuca również model Platona, czyli pochodzącą z dialogu Faidros metaforę rydwanu, dwóch rumaków i woźnicy ${ }^{24}$. Powód jest według biskupa Nyssy dość prosty. Jeśli dusza składa się z trzech części, to która z nich jest stworzona przez Boga, a jeśli wszystkie trzy części miałyby być uznane za stworzone przez Boga, to czym miałyby się wtedy od siebie różnić. Pisze o tym wprost w traktacie De hominis opificio: „W rzeczywistości dusza - prawdziwa i doskonała - jest jedna: rozumna i niematerialna, powiązana z naturą materialną dzięki zmysłom"25. Dusza zatem jest jedna, rozumna i niematerialna. Jednak Grzegorz z Nyssy dodaje coś, co w pewnym sensie antycypuje np. myśl filozoficzną Mistrza Eckharta. Dusza jest bezgrzeszna, co można również odczytać, że jest doskonała, oczywiście doskonała na tyle, na ile doskonały może być byt stworzony ${ }^{26}$. W traktacie De anima et resurrectione czytamy: „Bóg dał jej [duszy - przyp. M.M.] istnienie, a ponieważ w Bogu nie ma nawet śladu grzechu, również duszy nie można do niego zmusić" 27 . Stworzona przez Boga i będąca w tym aspekcie Jego obrazem i podobieństwem albo inaczej: mająca w sobie Jego obraz i podobieństwo, dusza, by mogła być prawdziwym obrazem i podobieństwem Boga, musi być bezgrzeszna, czyli nieskłonna do grzechu, a zatem - musi być jedynym miejscem w człowieku, także po grzechu pierworodnym, które jest zdolne do poznawania Boga.

\section{Grzegorza z Nyssy nauka o mistycznym przebóstwieniu}

Rozumienie mistycznego doświadczenia, jednej z kilku dróg poznawania Boga wskazanych nam przez Nysseńczyka, jest wypadkową pojmowania Boga oraz człowieka, jest zatem tym, co łączy w sobie teologię, kosmologię i antropologię. Problemem nie jest to, kto może poznać Boga, problemem nie jest to,

${ }^{24}$ Por. De anima, 42.

${ }^{25}$ De himinis opificio, XIV, 2. Według polskiego thumaczenia: Grzegorz z Nyssy, O stworzeniu człowieka, tłum. M. Przyszychowska, Kraków 2006, paginacja: cyfra rzymska oznacza rozdział, cyfra arabska - numer paragrafu. Por. De anima, 33.

${ }^{26}$ Eckhart oczywiście, mając na uwadze tę cechę duszy, będzie próbował wskazywać jej niestworzoność, jeśli nie w całości, to przynajmniej w jej najgłębszej części czy naturze, zwanej przez niego m.in. iskierką duszy czy warownym miasteczkiem.

27 De anima, 71. 
czy Bóg jest poznawalny, bo przecież samo Pismo Święte podkreśla, że poznanie Boga jest ,życiem wiecznym” (J 17,3), ale to, jak to jest możliwe wobec filozoficznej nauki o Bogu, mówiącej wprost, że jest On w swej naturze niepoznawalny. Próbując wyjaśnić to zagadnienie, biskup Nyssy wskazuje na trzy płaszczyzny, które, wzajemnie na siebie nałożone, dadzą właściwą odpowiedź.

Doświadczenie mistyczne jest specyficzne w tym sensie, że pomimo iż jest zawsze doświadczeniem jednoczącym, nie prowadzi do zjednoczenia, czyli henosis. Mówiąc wprost: w koncepcji doświadczenia mistycznego Grzegorza z Nyssy nie ma henosis rozumianego jako zjednoczenie poznającego z Poznawanym, czyli zatarcia różnicy między podmiotem poznającym a przedmiotem poznania. Bernard McGinn podkreśla to tak: „Tak jak współczesny mu święty Augustyn, Grzegorz nie mówi o mistycznej unii (henosis), mimo że używa terminów sugerujących mieszanie się, współdzielenie, wspólnotę i tym podobnych. Zasadniczy aspekt jego języka stanowi słownictwo wyrażające przemianę i przebóstwienie"28. Język pism biskupa Nyssy jest w wielu miejscach metaforyczny i obrazowy, bo tylko dzięki takiemu sposobowi wyrażania się możliwe jest pokonywanie trudności. W doświadczeniu mistycznym nie ma możliwości mówienia o unii mistycznej, o zjednoczeniu się czy o jakiejkolwiek unifikacji, ponieważ Bóg jest bytem niestworzonym a człowiek stworzonym, ponieważ ta różnica nigdy nie zostanie pokonana, ponieważ jest ona zasadnicza dla pojmowania Boga i człowieka. Człowiek jest z natury swej bytem stworzonym i tylko jako byt stworzony może poznawać Boga. Stąd, wedle Nysseńczyka możemy mówić w tym wypadku o mistycznym poznawaniu (a nie poznaniu), które jest przebóstwieniem ludzkiej stworzonej natury. Zostaje ona przebóstwiona, choć nadal pozostaje stworzona.

Doświadczenie mistyczne jest specyficzne również i z tego powodu, że nie ma w nim klasycznie pojmowanej mistycznej ekstazy jako wychodzenia poza ciało. Można jednak powiedzieć, że Grzegorz z Nyssy dokonuje pewnego przeformułowania rozumienia ekstasis, ponownie antycypując m.in. myślenie Mistrza Eckharta, choć w tym przypadku wzorcem dla Mistrza z Kolonii był chyba św. Augustyn. Doświadczenie mistyczne, jeśli ma mieć aspekt ekstatyczny, musi polegać na pozbywaniu się tego, co cielesne, a trzeba przez to rozumieć nie tylko cielesność jako taką, ale również i to, co jest materialne w człowieku, a zatem i wszelkie - materialne przecież - przedstawienia, obrazy, podobizny. Trzeba nawet zrezygnować z naturalnego przecież przywiązania do tego wszystkiego, co materialne wokół nas, z przywiązania do - materialnego przecież - myślenia o Bogu poprzez pojęcia czy wyobrażenia, bo zatrzymywanie się na poziomie pojęć czy wyobrażeń jest zatrzymywaniem się na poziomie idola, który nadal przesłania nam Boga. Georges Florovsky

28 B. McGinn, P. Ferris McGinn, Mistycy wczesnochrześcijańscy, dz. cyt., s. 108. 
podkreśla, że dla Nysseńczyka każda próba wprowadzenia jakiegokolwiek pojęcia czy określenia w mówieniu o Bogu, to skierowanie się w stronę id ol a ${ }^{29}$. Ekstaza byłaby zatem wychodzeniem poza cielesność, ale równoczesnym wchodzeniem $\mathrm{w}$ to, co najbardziej bliskie i pokrewne Bogu, a więc równocześnie wchodzeniem w głębię swej duszy, gdzie - pomimo upadku wciąż „tli się” czy „żarzy”, jak powiedziałby Mistrz Eckhart ${ }^{30}$, „obraz i podobieństwo Boga".

Jednak doświadczenie mistyczne jest specyficzne także poprzez to, że nigdy się nie kończy - jest właśnie poznawaniem, a nie poznaniem. Podkreślanie elementu epektasis jest charakterystyczne dla Grzegorza z Nyssy. Wynika ono - jak sądzę - z trzech powodów. Pierwszy powód jest natury metafizyczno-kosmologicznej i był już tu wielokrotnie przywoływany. Bóg jest bytem niestworzonym, a człowiek bytem stworzonym, i to jest niepokonywalna różnica. Przepaść pomiędzy tymi dwoma bytami, ta metafizyczna różnica, z natury swojej jest niepokonywalna, a to skutkuje tym, że poznawanie Boga, jakiekolwiek by ono było, nie jest w stanie tej diastema pokonać, stąd jest zawsze niekończącym się doświadczaniem Boga. Drugi powód jest natury metafizyczno-epistemologicznej. Bóg jest bytem z natury swej niepoznawalnym, czego wyrazem jest biblijne sformułowanie „Nikt nigdy Boga nie oglądał”. Jeżeli „nikt” i „nigdy”, to oznacza to metafizyczną tezę o absolutnej niepoznawalności natury Boga. $Z$ drugiej strony, ponieważ Biblia wprost mówi o tym, że życiem wiecznym jest poznanie Boga (J 17,3), biskup Nyssy pokazuje poznawalność Boga w tym, co jest - metaforycznie - ,wokół” Jego niepoznawalnej natury, a co jest Jego wypływami, działaniami, darami. Zatem, poznając to, co jest ,dookoła Boskiej Natury”, nigdy nie poznajemy tego, co jest „w środku” (na ikonach pokazane jest to w postaci ciemnego obszaru mandorli wokół Chrystusa na Górze Tabor), dlatego też takie poznanie jest niezakończone. Trzecim powodem jest to, co najczęściej wiąże się z próbami określania Boga jako Miłości. Jeżeli Bóg jest Miłością, a nasze Jego poznawanie jest miłowaniem, to z natury samej miłości wynika, że musi ona być nieskończona, to znaczy musi ona nie mieć końca. Zauroczenie może mijać, miłość trwa (jest) wiecznie (1 Kor 13,13). W traktacie De perfectione czytamy:

Paweł nazywa Chrystusa także „obrazem Boga niewidzialnego” (Kol 1,15), Bogiem ponad wszystkim i Bogiem wielkim. Takich bowiem określeń używa, głosząc wielkość Pana: „wielki Bóg i Zbawiciel Jezus Chrystus” (Tt 2,13), oraz

29 Por. G. Florovsky, The Eastern Fathers of the Fourth Century, The Collected Works, vol. 7, trans. C. Edmunds, Vaduz 1987, s. 160; S. Bułgakow, Światto wieczności. Medytacje i spekulacje, tłum. J. Chmielewski, Kęty 2010, s. 173.

${ }^{30}$ Por. Mistrz Eckhart, O człowieku szlachetnym, w: tenże, Dzieła wszystkie, tłum. W. Szymona, Poznań 2014, s. 164. 
„Z nich pochodzi również Chrystus według ciała, który jest ponad wszystkim, Bóg błogosławiony na wieki” (Rz 9,5). Mówiąc to, Apostoł uczy nas o Tym, który zawsze jest tym, kim jest (jedynie On wie, kim jest), a jeśli chodzi o ludzkie pojmowanie, przewyższa je zawsze $\mathrm{w}$ tej samej mierze, także, jeżeli człowiek „troszcząc się o to, co w górze” (Kol 3,2), czyni postępy i wciąż przybliża się do Niego ${ }^{31}$.

Z jednej strony możemy ten fragment odczytać jako naukę moralną i w pierwszym aspekcie o to zapewne Grzegorzowi tutaj chodziło. Człowiekowi dana jest droga nieustannego moralnego doskonalenia się, dana jako droga ciągłego upodabniania się do Boga. Ponieważ upodabniamy się do Boga, nigdy nie osiągamy celu, jakim jest sam Bóg. Możemy jednak odczytać ten fragment również epistemologicznie poprzez wskazanie, że pojmowanie Boga, przewyższając wszelki ludzki intelekt, może jedynie próbować zbliżać się poznawczo do Boga, nigdy Go nie osiągając. Zatem możliwe jest tylko nieskończone poznawcze zbliżanie się do Boga.

Grzegorz z Nyssy używa jeszcze jednego obrazu pokazującego epektatyczny charakter doświadczenia mistycznego. Znalazł go w życiu Mojżesza. Jego traktat De vita Moysis jest zupełnie dotąd niespotykanym rodzajem tekstu filozoficzno-teologicznego. Nysseńczyk w umiejętny sposób konstruuje alegorię mistycznej drogi ku Bogu, która jest swobodnym przetworzeniem biblijnej opowieści o Mojżeszu po to, aby pokazać jasny obraz patriarchy jako modelu człowieka doświadczającego Boga ${ }^{32}$. Z jednej strony biskup Nyssy podkreśla trzy momenty w życiu Mojżesza, kiedy to „widział” Boga - krzew gorejący, obłok i chmura na Synaju oraz widzenie „pleców”, czyli Chwały Boga - a z drugiej strony zauważa, że to poznawanie Boga zawsze miało miejsce na górze (albo góra była niejako w tle). Stąd ważne jest utożsamienie poznania Boga ze wspinaczką na górę ${ }^{33}$. Czytamy: „Poznanie Boga jest podobne do stromej i niedostępnej góry" 34 . Poznanie Boga, ale nie wszelkie poznanie, „podobne” jest do góry, a zatem mamy to traktować jedynie jako zręczną metaforę czy porównanie. Jednak Grzegorz zwraca tutaj uwagę na dwie cechy tej góry, które pozwalają porównywać ją z poznawaniem Boga. Po pierwsze, góra jest „niedostępna”. Owa niedostępność góry może być rozumiana na dwa sposoby: albo góra jest niedostępna, bo nie jesteśmy wprawieni w chodzeniu po górach czy też nie istnieje jeszcze bezpieczna droga prowadząca na szczyt,

31 De perfectione, dz. cyt., 48.

32 Por. B. McGinn, P. Ferris McGinn, Mistycy wczesnochrześcijańscy, dz. cyt., s. 107. Być może Grzegorz z Nyssy pisze tu także o sobie samym i swym własnym doświadczeniu.

33 Przypomina się w tym miejscu opis doświadczenia mistycznego jako wspinaczki na Górę Karmel u św. Jana od Krzyża, a później m.in. u Edith Stein czy Thomasa Mertona.

34 De vita Moysis, dz. cyt., II.158. 
co oczywiście łatwo jest naprawić, albo góra jest niedostępna sama w sobie, to znaczy jest tak uformowana, że jest nie do zdobycia, jest „niezdobywalna”. Właśnie taka góra jest metaforą poznania Boga, ponieważ metafizycznie jest On niepoznawalny w swej naturze. Po drugie, góra ta jest „stroma”, co oznacza, że wejście na nią wymaga nadzwyczajnego wysiłku ze strony zdobywcy, a co za tym idzie, również i długiego czasu wspinania się.

Nałożenie na siebie tych dwóch uszczegółowień pokazuje, że poznanie Boga, będące wspinaczką na „stromą i niedostępną górę”, jest nieustannym, wymagającym wysiłku doskonalenia się i pokonywania siebie, co więcej, niekończącym się wspinaniem, czyli wznoszeniem się ku Bogu. Doświadczenie mistyczne, będące wyjściem z siebie (ekstasis), wyjściem ze swej cielesności i materialności, porzuceniem przywiązania do tego, co materialne, i skierowaniem się ku temu, co duchowe i wewnętrzne (instasis) ${ }^{35}$, jest jednocześnie skierowaniem się ku niepoznawalnemu w naturze, a poznawalnemu w przejawach Bogu, jest nieustannym (epektasis) podążaniem ku „wyznaczonej nagrodzie” (Flp 3,13), ku przebóstwieniu (theosis) w niestworzonych boskich energiach.

\section{EKSTASIS I EPECTASIS - TWO ELEMENTS DESCRIBING THE MYSTI- CAL EXPERIENCES ACCORDING TO GREGORY OF NYSSA}

\section{Summary}

This text is an attempt to analyze fundamental aspects of Gregory of Nyssa's mystics. In a way of neoplatonic tradition, Gregory speaks on the God as transcendent the world, both - the material and the spiritual, and transcends the human knowledge. God is unknowable. In this kind of understanding, there are two fundamental aspects of Gregory of Nyssa's conception of mystical experience: ekstasis and epectasis. First, classical in the western kind of mysticism, is known as ,, a stay beyond the materiality". Human soul must desert the body and in this way see God. Second, because God is transcendent and unknowable, the human soul must go an unending way to God. It never reaches God Himself.

Keywords: Gregory of Nyssa; mysticism; epectasis; ekstasis; unknowability of God

Slowa kluczowe: Grzegorz z Nyssy; mistycyzm; ekstasis; epektasis; niepoznawalność Boga

35 Termin instasis, utworzony jako podobny do ekstasis, ma podkreślać doświadczenie polegające nie na „stawaniu obok/na zewnątrz”, a na wchodzeniu do wnętrza, czyli na „stawaniu wewnątrz". 


\section{BIBLIOGRAFIA}

Armstrong A.H., Platonic Elements in St. Gregory of Nyssa'a Doctrine of Man, „Dominican Studies", vol. 1, no. 2, 1948, s. 113-126.

Armstrong A.H., The Self-Definition of Christianity in Relation to Later Platonism, w: Jewish and Christian Self-Definition I: The Saping of Christianity in teh Second and Third Centuries, ed. E.P. Sanders, London 1984, s. 74-99.

Balás D.L., Methousia Theou. Man's Participation in God's Perfection According to Saint Gregory of Nyssa, ,Studia Anselmiana”, vol. 55, 1966.

Bułgakow S., Światto wieczności. Medytacje i spekulacje, thum. J. Chmielewski, Kęty 2010.

Crouzel H., Grégoire de Nysse est-il fondateur de la théologie mystique? Une controverse récente, „Revue d'ascétique et de mystique”, vol. 33, no. 130, 1957, s. 189-202.

Florovsky G., The Eastern Fathers of the Fourth Century, „The Collected Works”, vol. VII, trans. C. Edmunds, Vaduz 1987.

Grzegorz z Nyssy, De anima et ressurrectione, w: Grzegorz z Nyssy, Pisma wybrane, thum. W. Kania, Warszawa 1974, s. 27-97.

Grzegorz z Nyssy, Do Eustacjusza o Trójcy Świętej, w: Grzegorz z Nyssy, Drobne pisma trynitarne, thum. T. Grodecki, Kraków 2001, s. 80-90.

Grzegorz z Nyssy, Homilie do Eklezjastesa, tłum. M. Przyszychowska, Kraków 2009.

Grzegorz z Nyssy, O doskonatości, w: Grzegorz z Nyssy, O naśladowaniu Boga. Pisma ascetyczne, thum. J. Naumowicz, Kraków 2001, s. 59-97.

Grzegorz z Nyssy, O stworzeniu człowieka, tłum. M. Przyszychowska, Kraków 2006.

Grzegorz z Nyssy, Wielka mowa katechetyczna, w: Grzegorz z Nyssy, Pisma wybrane, thum. W. Kania, Warszawa 1974, s. 128-183.

Grzegorz z Nyssy, Życie Mojżesza, tłum. S. Kalinkowski, Kraków 2009.

Habra G., The Patristic Sources of the Doctrine of Gregory Palamas on the Divine Energies. Part II: The Three Cappadocians, „The Eastern Churches Quarterly”, vol. XII, no. 7, 1958, s. 294-304.

McGinn B., Obecność Boga. Historia mistyki zachodniochrześcijańskiej, tłum. T. Dekert, Kraków 2009.

McGinn B., Ferris McGinn P., Mistycy wczesnochrześcijańscy. Wizje Boga u mistrzów duchowych, thum. E.E. Nowakowska, Kraków 2008.

Mistrz Eckhart, $O$ człowieku szlachetnym, w: Mistrz Eckhart, Dzieła wszystkie, thum. W. Szymona, Poznań 2014, s. 155-174.

Pietras H., Początki teologii Ojców Kościoła, Kraków 2000.

Pseudo-Dionizy Areopagita, Teologia mistyczna, w: Pisma teologiczne, thum. M. Dzielska, Kraków 2005, s. 325-332.

Verghese T.P., Diastema and Diastasis in Gregory of Nyssa. An Introduction to a Concept and the Posing of a Problem, w: Zweites Internationales Kolloquium über Gregor von Nyssa, hrsg. von H. Dörrie, M. Altenburger, U. Schram, Leiden 1976, s. 243-260.

MACieJ Manikowski - prof. dr hab., profesor nadzwyczajny w Instytucie Filozofii Uniwersytetu Wrocławskiego, filozof i teolog. Zainteresowania naukowe: mistyka chrześcijańska, mistyka niemiecka XIV i XVII wieku, filozofia religii, filozofia dialogu, antropologia filozoficzna. Autor trzech monografii: Filozofia $w$ obronie dogmatu (Wrocław 2002), Pierwsza Zasada, świat stworzony i drogi poznania (Kraków 2006) oraz Bóg z perspektywy człowieka (Wrocław 2012). 